\title{
Indledning
}

\section{Historiske perspektiver på køn}

\section{Af Marie-Louise Holm, Morten Hillgaard Bülow \\ og Anne Folke Henningsen}

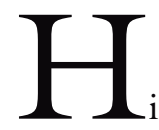

istoriske tilgange

har længe været en del af kønsforskningens mangfoldige metodologiske værktøjskasse og ikke kun blandt uddannede historikere. I dette nummer er det således ikke blot 'kønshistorie' (som en af mange bindestregshistorier såsom krigshistorie og medicinhistorie), vi sætter fokus på, men bredere forstået historiske perspektiver på køn. Eller sagt endnu mere præcist: i de følgende tekster undersøges det, hvordan historie som perspektiv og metode kan give os specifikke indsigter i køn.

Når man gerne vil undersøge køn som fænomen og producere viden om, hvordan $k ø n$ konstrueres i forskellige kontekster, i relation til forskellige tilgængelige begreber, og på mangfoldige måder, så giver det god mening at anlægge et historisk perspektiv på køn. Ikke nok med, at køn gøres forskelligt, lige nu, forskellige steder i verden; dét, vi måske tager som en selvfølge i denne del af verden, har også en historie og er blevet gjort, begrebsliggjort og har set 
anderledes ud tidligere. Ofte kan et historisk perspektiv være med til at anskueliggøre ikke blot, hvorfor noget er på en bestemt måde i nutiden, men også hvilke processer og omstændigheder, der har medvirket til, at det er blevet sådan. Dermed bliver det også muligt at overveje, hvordan det, der findes i nutiden, kunne have været anderledes, hvis historien havde foldet sig anderledes ud. At blive præsenteret for flere mulige fortider kan desuden virke inspirerende ved at give indsigt i radikalt anderledes sociale konfigurationer og begreber, som kan stimulere os til at tænke og forstå nutidens på nye måder og åbne op for, hvordan vi kan forestille os flere forskellige mulige fremtider ud fra vores aktuelle situation.

$\mathrm{Vi}$ vil i denne indledning introducere til en del af den forskning og de tilgange, der kombinerer et historisk perspektiv med et fokus på køn. Historisk set voksede interessen for denne kombination i høj grad ud af de debatter som aktivister i 1960'ernes kvindebevægelse rejste, og som samtidige kønsforskere tog op, men også før dette havde fx den franske filosof Simone de Beauvoir skrevet om køns historiske foranderlighed i sit klassiske værk Det tredje køn (1999). En anden udgivelse, som i høj grad var med til at skabe debat omkring den teoretiske tilgang til køn i historieforskningsmiljøer i 1980'erne, og som inspirerede mange forskere til at anvende et poststrukturalistisk perspektiv, var den amerikanske historiker Joan Scotts artikel Gender: A Useful Category of Historical Analysis (1986). Siden da har feltet udviklet sig og er blevet veletableret, som man kan læse om i fx kapitlet om 'køn og historie' i den tyske Handbuch Frauen- und Geschlechterforschung (Richter og Schraut 2008), og i dag findes bl.a. det internationale tidsskrift Gender \& History, som er dedikeret til at publicere forskeres teoretiske og empiriske vidensproduktion på området.

I en dansk kontekst er dette forskningsfelt relativt lille og spredt, men det repræs- enterer samtidig en mangfoldighed af temaer og tilgange, der også genfindes $i$ international forskning. På den baggrund har vi ønsket at bruge anledningen til at samle og tydeliggøre for Kvinder, Køn \& Forsknings læsere, hvilke former for forskning med et historisk perspektiv på køn, der er blevet bedrevet i en dansk kontekst, og hvilke erkendelsesinteresser, der har drevet denne forskning. Vi fokuserer således i denne introduktion på studier lavet af danske forskere eller om danske forhold, og samtidig fungerer de projekter og værker, der præsenteres i det følgende, som et prisme, der giver indblik $\mathrm{i}$ det internationale felts emner og tendenser. Læsere, der ønsker at få et indblik i, hvordan den forskning, der præsenteres her, er placeret $i$ en nordisk kontekst, vil vi anbefale at læse den norske historiker Dunja Blaževićs ph.d.-afhandling Jakten på et fagfelt: Den skandinaviske kvinne- og kjonnshistoriens fremvekst $i$ skjeringsfeltet mellom historieforskning og kvinne- og kjønssforskning (2015). Den følgende introduktion skal ikke ses som udtømmende - flere værker og forskere kunne være nævnt - men vi har forsøgt at nævne både dem, der historisk set har haft en betydelig indflydelse på feltet i en dansk kontekst, og give eksempler på nyere forskning, som bygger videre på og kendetegner feltet i dag.

Som anført ovenfor kan man overordnet set se den historieforskning, der har været interesseret i kønsperspektiver, som txt forbundet med interesserne inden for kønsforskningen i mere bred forstand. Selv om det altid er en historisk generalisering at tale om perioder eller forsøge at kategorisere forskning ud fra overordnede tendenser, så beskriver man ofte kønsforskningens historik som en bevægelse fra kvindeforskning til kønsforskning med øget fokus på intersektionelle perspektiver og poststrukturalistiske pointer. På samme vis kan man overordnet se de historiske perspektiver på køn som nogle, der har bevæget sig fra kvindehistorie til kønshistorie med stadig bredere 
inddragelse af intersektionel- og poststrukturalistisk teori, inspireret af fx Foucault og queer teori. Det er dog vigtigt at understrege, at mange forskere kombinerer, og har kombineret, forskellige tilgange og perspektiver, der er blevet etableret og har været særligt udbredt i forskellige årtier. Man bør derfor snarere tale om parallelle og overlappende tendenser end en decideret periodisering $\mathrm{i}$ forhold til forskning med historiske perspektiver på køn.

I det nedenstående har vi valgt at beskrive feltet tematisk med et særligt fokus på forskning, der kan placeres inden for traditionerne 'herstory', seksualitetshistorie, medicinhistorie og mande- og maskulinitetshistorie. Denne tematiske inddeling afspejler en overordnet tendens, som vi ser i forskningsinteresser inden for feltet, men som vi skal se passer sådanne beskrivelser ikke fuldstændig på de konkrete forskningsprojekter, som godt både kan indeholde 'kvindehistorie' og intersektionelle pointer, eller 'gøre' herstory i forhold til seksualitetsproblematikker.

\section{HERSTORY:}

KØN, POLITIK OG PRIVILEGIER

Det interessante ved historiske perspektiver er, at alt kan siges at have en historie, men det er ikke alt, der bliver skrevet historie om. Hvad og hvem, der bliver skrevet om, hvem, der får lov til at skrive historien, og hvordan denne historie bliver fremstillet, kan derfor siges at være et politisk interessant spørgsmål. Dette tydeliggøres eksempelvis af et begreb som herstory, der i 1970'erne blev formuleret som et modsvar til et ofte dominerende mandeperspektiv i traditionel history. Herstory-forskere har således påpeget, at de historier, der traditionelt er blevet fortalt inden for historieforskning, overvejende har repræsenteret interesser, der understøttede et mandligt, hvidt, heteroseksuelt, såkaldt rationelt middelklassesubjekt, både som centrum for den historie, der blev fortalt, og som den mest legiti- me producent af historisk (og anden videnskabelig) viden (Hall 1992). Dermed er perspektiver ud fra andre former for erfaringer og interesser, særligt kvinders, blevet marginaliseret.

Forskere med en implicit eller eksplicit herstory-tilgang har ønsket at råde bod på dette ved at tilføje nogle af de manglende perspektiver og former for viden. I en dansk kontekst var det eksempelvis banebrydende og utraditionel historieforskning, der blev bedrevet, da historikeren Bente Rosenbeck skrev bogen Kvindekøn: Den Moderne Kvindeligheds Historie 1880-1980 (1990), som ikke blot skrev kvinder ind i dansk historie, men også gjorde dette ud fra et hverdags- og familieperspektiv. Historikeren Anette Warrings bog Tyskerpiger: Under besettelse og retsopgor (1994) bidrog nogle år efter til at igangsætte offentlig debat om synet på danske kvinder, der havde seksuelle og/eller romantiske forhold til tyske soldater under besættelsen, og som efter krigen meget entydigt var blev fremstillet som landsforrædere og stikkere og afstraffet symbolsk og korporligt. Og før dette havde historikeren Kirsten Geertsen udgivet Arbejderkvinder i Danmark: Vilkar og kamp, 1924-1939 (1982), der ligesom historiker Birgitte Possings bog Arbejderkvinder og Kvindearbejde $i$ København ca. 1870-1906 (1980), belyste forholdene for nogle af de første kvinder, der for alvor kom ud på arbejdsmarkedet og bidrog til at tjene til deres familiers ophold.

Possings nyudgivne populærvidenskabelige bog, Argumenter imod kvinder (2018), kan ligeledes ses som et helt aktuelt eksempel på herstory. Bogen beskriver kvinder, der fra 1850-2018 har været banebrydende i en dansk offentlighed i forhold til synet på og politikker omkring bl.a. stemmeret, xgteskab, adgang til uddannelse, politik og sport, samt ikke mindst den modstand imod og forsøg på underkendelse af disse kvinders synspunkter og virke, der har været og desværre stadig findes. Possings fokus på argumenterne imod disse ambi- 
tiøse og kompetente kvinder, og på, hvordan de er lykkedes på trods af modstand, bibringer et nyt perspektiv at anskue den historiske udvikling af kampen for kønslig ligestilling - og forsøgene på at gøre denne historie tavs - ud fra.

Flere nyere eksempler kan nævnes. Eksempelvis historiker og journalist Nina Trige Andersens prisvindende bog Profession: filippiner - Kvinder på arbejde $i$ Danmark gennem fire årtier (2013), som ved hjælp af fire kvinders historie - fra ankomst til dansk statsborgerskab - belyser den danske velfærdsstats udvikling samt problematikker omkring arbejdsmigration og global ulighed. Andersen har bidraget til dette nummer med et essay, som ligeledes giver os nye perspektiver på 'filippinernes danmarkshistorie' - mere om dette senere. Andre eksempler er historikeren Astrid Elkjær Sørensens ph.d.-projekt, udgivet som bogen Pene pigers opror: Ligestillingsprojekter $i$ de kvindedominerede fagforbund 1985-2010 (2018), som har sat fokus på klasseaspekter af kvinders kamp for ligeløn i nyere dansk historie; samt det større nordiske projekt Agteskab $i$ Norden. Modernisering og kønskonstruktion, som sætter fokus på kampen for lige rettigheder i relation til udviklingen af xgteskabsinstitutionen $\mathrm{i}$ det 20. århundredes tre første årtier. Sidstnævnte projekt forløb mellem 1996 og 2006 som et samarbejde mellem Bente Rosenbeck, den norske historiker Kari Melby, den finske retsforsker Anu Pylkkänen og den svenske historiker Christina Carlsson Wetterberg (se https://koensforskning.ku.dk/forskning/afsluttede-projekter/agteskab/).

Fælles for disse projekter kan siges at være en insisteren på at bringe et kønsperspektiv ind i centrale dele af velfærdsstatens historie - klasse, arbejdsvilkår, ægteskab, migration, hverdagsliv, med mere - og derigennem giver de os en større forståelse for ikke blot fortiden, men også den nutidige kontekst, vi befinder os i.

\section{KØN, SEKSUALITET OG MAGT}

Hvor herstory-traditionen ofte fokuserer på kvindekategorien - med blik for forskellige andre intersektionelle kategorier som 'migrant' og 'arbejderklasse' - kan ønsket om at tilføje andre stemmer og fortællinger til den dominerende forståelse af velfærdsstatens historie også ses i et bredere perspektiv. Som kritisk værktøj kan historie være med til at sætte fokus på kønnede magtforhold på en lang række områder, nogle gange blot ved at skrive om vilkårene for dem, der ikke før er blevet skrevet om, andre gange med eksplicit foucauldiansk, feministisk og/eller queer-teoretisk inspiration.

Fra 1980'erne og frem begyndte danske forskere eksempelvis også at sætte fokus på forskellige opfattelser af seksuelle relationer mellem mennesker og/eller forholdene for forskellige seksuelle minoriteter igennem historien. I en dansk kontekst var folkemindeforsker Karin Lützens Hvad hjertet begerer (1986) den første - og den dag i dag stadig en af de eneste - historiske beretning om kvinder, der havde romantiske og/eller erotiske kærlighedsforhold til kvinder, skrevet i en dansk kontekst.

Tilsvarende kan historiker Wilhelm von Rosens afhandling Månens kulor: Studier $i$ dansk bøssebistorie 1628-1912 (1993) nævnes som et første bidrag til at få skrevet homoseksuelle mænd ind i danmarkshistorien. Von Rosens studie er senere blevet efterfulgt og suppleret af bl.a. historiker Peter Edelbergs ph.d.-afhandling Storbyen trekker. Homoseksualitet, prostitution og pornografi $i$ Danmark 1945-1976 (2012) og for ganske nyligt historiker Niels Nyegårds ph.d.-afhandling Perverse forbrydere og gode borgere: Homoseksualitet, heteronormativitet og medborgerskab $i$ Københavns offentlighed, 1906-11 (2018), som vi skal stifte nærmere bekendtskab med efter denne indledning.

Litteraturforskeren Dag Heedes queerteoretiske analyser af bl.a. Karen Blixens (Heede 2001), Herman Bangs (Heede 2003) og H.C. Andersens (Heede 2005) forfatterskaber kan også nævnes som studi- 
er, der var med til at introducere nye perspektiver på køn og seksualitet i læsninger af nogle af de mest fejrede historiske danske forfattere.

\section{KøN, MEDIKALISERING OG DISCIPLINERING}

Seksualitetsperspektivet handler lige som det tidligere beskrevne herstory-perspektiv også om at få skrevet aspekter frem, som giver os en større forståelse, ikke blot for, hvad folk har gjort for at tilkæmpe sig plads i et samfund, der på forskellig vis har søgt at disciplinere eller gøre dem tavse, men også af, hvilke konsekvenser sådanne disciplinerings- og tavshedsforsøg kan have. Som et vigtigt eksempel kan nævnes historiker Birgit Kirkebæks studie Letferdig og losagtig: Kvindeanstalten Sprogø 1923-1961 (2004), som omhandler unge ugifte, seksuelt aktive arbejderklassekvinder, som i 1930'erne blev diagnosticeret som lettere åndssvage og interneret, og som ofte blev presset til at lade sig sterilisere for at blive sluppet ud igen. Kirkebæks forskning belyser desuden, hvilke konsekvenser forskellige former for medicinsk vidensproduktion har haft for tilgangen til og behandlingen af bestemte samfundsgrupper. Et andet eksempel på denne slags medicinhistorisk forskning med et køns- og seksualitetsperspektiv er historiker Jesper Vaczy Kraghs bog Det hvide snit: Psykokirurgi og dansk psykiatri 1922-1983 (2010). I bogen viser Kragh, hvordan omkring $70 \%$ af de personer, der blev lobotomeret i den nævnte periode, var kvinder, der brød med forventninger om traditionel feminin opførsel ved at opføre sig på måder, der i samtiden blev beskrevet som aggressivt, (seksuelt) uanstændigt og somme tider voldeligt, og som var blevet diagnosticeret som psykopater på grund af dette.

Også inden for medicinhistorie, kombineret med ny kønsforskning, kan nævnes temaredaktør Marie-Louise Holms ph.d.afhandling Fleshing out the self: Reimagi- ning intersexed and trans embodied lives from (auto)biographical accounts of the past (2017). Ud fra en læsning af selvbiografiske beretninger fra perioden 1900-1973 sætter Holm her spørgsmålstegn ved senere årtiers dominerende forestillinger om, hvilke kroppe og liv transpersoner og interkønnede personer må have for at kunne opnå levbare liv. I afhandlingen vises desuden, hvordan rets- og lægevidenskabelige eksperter på den ene side tillod en række borgere at skifte navn, juridisk kønsstatus og klædedragt og på den anden side indførte begrænsninger for kønnede udtryks- og livsmuligheder ved bl.a. at gøre fjernelse af kønskirtlerne til et krav for at opnå tilladelse til skift af juridisk kønsstatus og navn.

I bogen Menneskeudstilling. Fremvisninger af eksotiske mennesker $i$ Tivoli og Zoologisk Have (2011) af historiker Rikke Andreassen og temaredaktør Anne Folke Henningsen er kønsopfattelser og intersektioner mellem køn og racialisering et vigtigt analytisk knudepunkt. De to forskere viser, at et sådant fokus kan foranledige nye forståelser af, hvordan køn og race spillede sammen i iscenesættelserne af 'eksotiske' mænd og kvinder i de spektakulære levende etnografiske udstillinger, der sigtede på at have et både videnskabeligt oplysende og underholdende formål for den hvide, danske tilskuer. Samtidig undersøger Andreassen og Henningsen også, hvordan interraciale romantiske og/eller seksuelle relationer mellem udstillede mænd og danske kvinder blev forstået, vurderet og praktiseret i samtiden.

Et fælles formål for de nævnte forskningsprojekter er, at de alle søger at belyse magtmekanismer og -relationer mellem lægevidenskabelige autoriteter og forskellige borgere, både på et mere overordnet institutionelt niveau, men også ofte ud fra studier af enkeltpersoners sager. En sådan forskningstilgang bibringer indblik i, hvordan lægevidenskabelig vidensproduktion og institutionspraksisser har produceret normalitets- og abnormalitetsopfattelser og - 
normer, og hvordan disse har været - og somme tider fortsat er - grundlag for disciplinering og regulering af borgere $\mathrm{i}(\mathrm{og}$ uden for) Danmark.

\section{KRITISKE PERSPEKTIVER PÅ MÆND OG MASKULINITETER?}

Som ovenstående studier viser, kan historiske perspektiver på køn dreje sig om mange forskellige dele af livet - på både individ og samfundsniveau - og om personer med mange forskellige intersektionelle kategorier i spil. Som nævnt kan de historiske perspektiver på køn også sige noget om, hvilke problematikker og emner, forskere med interesse i køn, har set som mest relevante at beskæftige sig med på forskellige tidspunkter. Studier med et eksplicit fokus på køn i forhold til mænd og/eller maskuliniteter er eksempelvis forholdsvis sjældne i en dansk kontekst $\mathrm{i}$ forhold til i de andre nordiske lande, og der er efter vores mening et stort potentiale for at udvikle feltet på dette område $\mathrm{i}$ fremtiden. En pointe fra kritiske mande- og maskulinitetsstudier er eksempelvis, at en feministisk analyse af magtrelationer mangler en vigtig komponent, hvis der ikke også rettes et kritisk og nuancerende blik på mænd og maskuliniteter.

For læsere, der er interesseret i en bredere indføring i flere forskellige temaer inden for historisk forskning om mænd og maskuliniteter, er den svenske idéhistoriker Claes Ekenstams og den norske litteraturforsker Jörgen Lorentzens antologi Män $i$ Norden: Manlighet och Modernitet 1840-1940 (2006) et godt sted at starte. I denne antologi bidrager forskere fra de nordiske lande med analyser med et fokus på majoritetskultur og -kønsnormer i forskellige samfundsklasser.

I en dansk kontekst er sådanne studier yderst sjældne. Et af de få danske studier med et sådant kønsperspektiv er historikeren Laura Skardhamars ph.d.-afhandling "Det private er politisk" - En analyse af et kollektiv, olejre og mandebevegelse $i$ de lange halvfjerdsere i Danmark (2010). Her følges udviklingen af mandebevægelsen i Danmark i løbet af 1970'erne med fokus på mandeaktivisters oprørs- og frigørelsesprojekter om krop, seksualitet, følelser, alternative mandefællesskaber og børneomsorg. Et andet eksempel er bogen Det stof mand er gjort af: Konstruktionen af maskulinitetsbegreber $i$ forskningsprojekter om testosteron $i$ Danmark fra 1910'erne til 1980'erne (2013), skrevet af to af dette nummers temaredaktører, Marie-Louise Holm og Morten Hillgaard Bülow. I studiet foretages en kritisk undersøgelse af, hvordan testosteron og begreber om maskulinitet blev sammenkoblet i hormonforskning udført i Danmark igennem en periode på 70 år, og Holm og Bülow viser, hvordan alternative og mindre eksplicit kønnede opfattelser af det, der i dag kaldes kønshormoner, blev marginaliseret eller forladt undervejs i historiens løb.

\section{NyE PERSPEKTIVER: DETTE NUMMER}

Som det er fremgået af ovenstående præsentation af tilgange til og tematikker forbundet med køn og kønnede processer i historisk perspektiv, har teoretiske brud og nybrud længe spillet en rolle inden for kønshistoriefeltet ligesom i den øvrige kønsforskning. Mange af de nævnte forskere har været medvirkende til på forskellig vis at introducere teoretiske perspektiver $\mathrm{i}$ deres empiriske analyser og har derigennem åbnet for nye læsninger og forståelser af historiske fænomener. Afslutningsvis vil vi gerne pege på yderligere et væsentligt bidrag, nemlig fra Dorthe Gert Simonsen, der i sin specialeafhandling Konnets grenser (1996) og artiklen Som et stykke vadt sebe mellem fedtede fingre (1996) gennemførte et stort teoretisk arbejde, der var medvirkende til at introducere og argumentere for potentialerne i poststrukturalistiske analysestrategier i (køns)historien i en dansk kontekst. Den gennemgående interesse for teoretisk refleksion, som kendetegner megen 
kønsforskning, vil også kunne ses i artiklerne trykt i dette nummer.

Selv om vi er relativt få historikere og historisk interesserede kønsforskere, der beskæftiger os direkte med historiske perspektiver på køn (og seksualitet, nationalitet, race, klasse, alder og andre intersektionelle kategorier), så kommer der hele tiden nye til. Historie synes at være et uudtømmeligt emne, der hele tiden kan udforskes fra nye vinkler med nye kilder og nye tilgange. $\mathrm{Hi}$ storiske perspektiver på køn dækker dog også over andet end at lægge nye vinkler på og skabe ny viden om fortiden. Som to af artiklerne i dette nummer viser, kan historiske perspektiver også handle om, hvordan historien er blevet brugt i nutiden. Eksempelvis kan historie bruges i nationalistisk øjemed til at appellere til og konstruere en fælles national historie, hvor man ikke adskiller mænd og kvinder i svømmeundervisning (jf. Ernberg, dette nummer) - eller til at skabe et mod-kolonialt fællesskab blandt en ikke-heteronormativ minoritet i en amerikansk kontekst (Kongerslev, dette nummer). Sådanne former for historiebrug er interessante at analysere, idet de ofte siger mere om nutiden og de bekymringer, fællesskaber og magtkampe, som søger legitimering i en (ofte forestillet) fortid, end de siger om reelle historiske begivenheder.

Temanummeret begynder dog et andet sted, nemlig med et interview med kønsog seksualitetshistoriker Niels Nyegaard, der for nyligt forsvarede sin ph.d.-afhandling. Marie-Louise Holm fra temaredaktionen har spurgt Nyegaard om hans inspirationskilder, forhold til teori og bidrag til eksisterende forskning samt om, hvilke perspektiver hans historiske projekt giver på nutiden, og hvad han ser som væsentlige problematikker på feltet. Nyegaards svar giver et godt indblik i ph.d.-projektets pointer om de komplekse sammenhænge mellem konstruktioner af (mandlig) homoseksualitet og moderne medborgerskab, og Nyegaard peger samtidig både tilbage på de dele af feltet, som hans forskning er inspire- ret af, og mod fremtidige inspirationer og problematikker for andre, der vil beskxftige sig med lignende emner.

Efter interviewet følger temanummerets første peer review artikel, som er en begrebshistorisk analyse af, hvordan og under hvilke omstændigheder begrebet 'kvinde' blev introduceret i en dansk kontekst. Lone Kølle Martinsen, Jesper Lundsby Skov og Sissel Bjerrum Fossat tager i Kampen om kvinden: Begrebshistoriske perspektiver et første skridt mod at undersøge kvindebegrebets brug og udbredelse efterhånden som dette blev et nyt grundbegreb, der med hjxlp fra velkendte romantiske digtere som Oehlenschläger og Grundtvig - erstattede andre ord som $\mathrm{fx}$ 'fruentimmer' og med tiden blev et centralt begreb for bl.a. kvindebevægelsen.

Dernæst sætter Marianne Kongerslev fokus på kolonial og mod-kolonial historieskrivning i artiklen Dance to the Two-Spirit: Mythologizations of the Queer Native, som navigerer i det komplekse forhold mellem fortid, nutid, poesi og historiebrug. Kongerslev viser, hvordan konstruktionen af den 'queer indfødte' har været brugt både som en kolonial elimineringsstrategi (det 'mærkelige' og 'afvigende' har legitimeret kolonialismens indgreb) og som en - ligeså kolonial og eliminerende - legitimeringsfigur for moderne homoidentiteter (hvor historien om den 'queer indfødte' bruges til at historicere og naturliggøre hvide koloniale seksualiteter). Over for dette stilles digte og poesi skrevet af indfødte selv, som bruger en lignende historisk figuration kaldet "Two-Spirit" til at kritisere det koloniale 'hetero-patriarki' og skabe plads og modmagt imod den koloniale (udslettende) fortælling.

Mathilda Ernbergs artikel I bassäng med nationen introducerer os derefter til en anden politisk debat, som for få år siden udspillede sig i de offentlige medier i Danmark, og som i Ernbergs analyse handler om forhandlinger af diskursiv magt, nationalisme og historiebrug. Ernberg under- 
søger således i sin artikel, hvordan debatten om kønssegregerede svømmehaller i den danske offentlighed blev skueplads for politiske debatter om 'danskhed' og nationalisme, og påpeger, hvordan ideen om en fælles national historie her blev brugt som diskursivt magtredskab til at forsøge at ekskludere bestemte kroppe og praksisser fra fællesskabet.

Efter Ernbergs artikel følger et længere historisk essay skrevet af Nina Trige Andersen, som både bidrager til herstory, klasseog fagforeningshistorie samt migrationshistorie i Danmark. Andersen har i længere tid forsket i filippinske såkaldte gxstearbejderes vilkår og betydning for bl.a. fagforeningshistorie. Dette grundige historiske essay viser, hvordan de kvindelige filippinske fagforeningsledere og -aktivister var afgørende for de sejre, fagforeningerne kunne mønstre i især 1990'erne - og hvordan dette er en historie, de officielle fagforeningshistorier ikke selv nævner.

Som sidste artikel i dette nummer bringer vi en uden-for-tema artikel, Voksne etniske minoritetsmend, marginalisering og intersektionalitet, af Sune Qvotrup Jensen, Jeppe Fuglsang Larsen og Ann-Dorte Christensen. Artiklen bidrager med kvalitative interviews og en intersektionel analyse af såkaldt etniske minoritetsmænds sociale problemer i en forstad til Aalborg. Analysen peger på, hvordan disse sociale problemer opstår gennem komplekse sammenhænge mellem et system, der er dårligt lavet til at hjælpe dem, maskulinitetsudfordringer relateret til mændenes klassebaggrunde, samt kønsspecifikke oplevelser af andetgørelse og racisme. Intersektionalitetsperspektivet bruges her konkret og nuanceret i forhold til materialet, og artiklen rækker samtidig ud over dets empiriske materiale med teoretiske refleksioner, der vil kunne bruges som inspiration til andre intersektionelle analyser inden for kønsforskningen. Som forfatterne selv påpeger, muliggør det intersektionelle perspektiv en radikal åbenhed over for de forventninger og forforståelser, man som kønsforsker kan have, i forhold til hvem man ser som privilegerede eller dominerende.

Vi har med dette temanummer ønsket dels at spørge, hvor de historiske perspektiver på køn er henne nu - hvad er de væsentlige emner, problematikker, etiske og metodiske spørgsmål, som træder frem i historiske tilgange til køn i dag? Og dels har vi ønsket at samle forskellige tilgange og perspektiver på køn og historie i dette nummer for derigennem at opfordre til debat og videre udvikling af disse tilgange. Vi har i temaredaktionen ikke tænkt dette nummer som (blot) et kønshistorisk temanummer, hvor kønnede individer og kønskategorier er genstand for traditionel faghistorisk undersøgelse, men (også) et temanummer, hvor både kønskategorier og metodologiske historiske værktøjer tages op til eftersyn. Historie som tidslighed, situation og fortælleform er netop væsentlig som perspektiv på køn (og andre emner), fordi dette kan give nye perspektiver på dét, som tages for givet i nutiden, og fordi historien samtidig bliver meningsfuld ud fra og peger på, hvad der ses som vigtigt i en nutidig kontekst. Med andre ord er historie et refleksivt felt, hvor også historiefagets tilgange og ikke mindst fremstillingsformer kan være vigtige at belyse.

Marie-Louise Holm, cand. mag. i historie og filosofi/videnskabsteori og ph.d. $i$ konsforskning. Ekstern lektor på det Natur-og Biovidenskabelige Fakultet, Kobenhavns Universitet.

Morten Hillgaard Bülow, cand. mag. $i$ historie og filosofi/videnskabsteori og ph.d. $i$ sundhedsvidenskab. Ekstern lektor pà det Sundhedsvidenskabelige Fakultet, Kobenhavns Universitet.

Anne Folke Henningsen, cand. mag. og ph.d. i historie. Lektor $i$ etnologi på Saxo-Instituttet, Københavns Universitet. 


\section{LITTERATUR}

- Andersen, N. T. 2013. Profession: filippinerKvinder på arbejde i Danmark gennem fire ärtier. København: Tiderne Skifter.

- Andreassen, R. og Henningsen, A. F. 2011. Menneskeudstilling: Fremvisninger af eksotiske mennesker i Zoologisk Have og Tivoli. København: Tiderne Skifter.

- de Beauvoir, S. 1999. Det andet Køn. Første Bind: Kendsgerninger og Myter (4. udgave). Viborg: Tiderne Skifter.

- Blaževi, D. 2015. Jakten på et fagfelt: Den skandinaviske kvinne- og kjønnshistoriens fremvekst $i$ skjaringsfeltet mellom historieforskning og kvinneog kjønssforskning. Ph.d.-afhandling, Universitetet i Bergen.

- Edelberg, P. 2012. Storbyen trakker. Homoseksualitet, prostitution og pornografi i Danmark 19451976. København: Jurist- og Økonomforbundets Forlag.

- Geertsen, K. 1982. Arbejderkvinder i Danmark: Vilkar og kamp, 1924-1939. København: SFAH skriftserie, nr. 13.

- Hall, C. 1992. White, Male and Middle Class: Explorations in Feminism and History. Cambridge, UK \& Malden, USA: Polity Press.

- Heede, D. 2001. Herman Bang: Merkvardige lesninger, toogfirs tableawer. Odense: Syddansk Universitetsforlag.

- Heede, D. 2003. Det umenneskelige: Analyser af seksualitet, køn og identitet hos Karen Blixen.

Odense: Syddansk Universitetsforlag.

- Heede, D. 2005. Hjertebrødre: Krigen om H.C. Andersens seksualitet. Odense: Syddansk Universitetsforlag.

· Holm, M. og Bülow, M. H. 2013. Det stof mand er gjort af: Konstruktionen af maskulinitetsbegreber i forskningsprojekter om testosteron $i$ Danmark fra 1910'erne til 1980'erne. København: Varia: Udgivelser fra Center for Kønsforskning, nr. 10. Tilgængelig på: http://koensforskning.ku.dk/nyeudgivelser/varia/Det_stof_m_nd_er_gjort_af_-_Varia_2013.pdf.

- Kirkebæk, B. 2004. Letfardig og losagtig: Kvindeanstalten Sprogø 1923-1961. Holte: Forlaget

SocPol.
. Lützen, K. 1986. Hvad Hjertet begarer: Kvinders Korlighed til Kvinder 1825-1985. København: Tiderne Skifter.

- Nyegaard, N. 2018. Perverse forbrydere og gode borgere: Homoseksualitet, heteronormativitet og medborgerskab i Københavns offentlighed, 1906-11. Ph.d.-afhandling, Aarhus Universitet.

- Possing, B. 1980. Arbejderkvinder og Kvindearbejde $i$ København ca. 1870-1906. Aalborg: Aalborg Universitetsforlag.

- Possing, B. 2018. Argumenter imod kvinderFra demokratiets barndom til i dag. København: Strandberg Publishing.

- Richter I. og Schraut S. 2008. Geschichte: Geschlecht und Geschichte. I: Becker R. og Kortendiek B. red. Handbuch Framen- und Geschlechterforschung. VS Verlag für Sozialwissenschaften, 722-729. DOI:10.1007/978-3-531-91972-0_86 - Rosenbeck B. 1990. Kvindekøn: Den Moderne Kvindeligheds Historie 1880-1980. København: Gyldendal.

- Scott, J. W. 1986. Gender: A Useful Category of Historical Analysis. The American Historical Review. 91(5), 1053-1075.

- Simonsen, D. G. 1996. Konnets gronser: poststrukturalistiske strategier - historieteoretiske perspektiver. København: Center for Kvinde- og Kønsforskning, Varia, nr. 1.

- Simonsen, D. G. 1996. Som et stykke vådt sæbe mellem fedtede fingre. Kvinder, Køn o Forskning. 5(2), 29-50.

- Skardhamar, L. P. 2010. "Det private er politisk"

- En analyse af et kollektiv, olejre og mandebevagelse $i$ de lange halvfjerdsere $i$ Danmark. Upubliceret ph.d.-afhandling, Roskilde Universitet.

- Sørensen, A. E. 2018. Pane pigers opror: Ligestillingsprojekter $i$ de kvindedominerede fagforbund 1985-2010. Aarhus: Aarhus Universitetsforlag. - von Rosen, W. 1993. Mànens kulør: Studier $i$ dansk bøssehistorie 1628-1912. København: Rhodos.

- Warring, A. 1994. Tyskerpiger: Under besettelse og retsopgør. København: Gyldendal. 